\title{
The Effect of Soil Conditioners and Weather on Lawn Appearance
}

\author{
Kazimierz Jankowski ${ }^{1}$, Milena Truba ${ }^{1 *}$, Elżbieta Malinowska ${ }^{1}$, \\ Beata Wiśniewska-Kadżajan
}

1 Department of Grassland and Green Areas Creation, Siedlce University of Natural Sciences and Humanities, ul. Prusa 14, 08-110 Siedlce, Poland

* Corresponding author's e-mail: milena.truba@uph.edu.pl

\begin{abstract}
The aim of this study was to determine the suitability of lawn grasses cultivated in monoculture and fertilizated by soil conditioners to establish lawn grasses used extensively in terms of their impact on the overall aspect. The following grass species were used in the experiment: Lolium perenne, Festuca rubra and Poa pratensis. They were sown on their own, each of them at the rate of $28 \mathrm{~g} \cdot \mathrm{m}^{-2}$. Another experimental factor tested in the research was soil conditioners - Substral, Humus Activ Papka, Eko-Użyźniacz, UG-max. At the end of each growing season, between 2013 and 2015, an assessment of grass was carried out. Among other things its general appearance was assessed using a 9-point rating scale. This assessment was conducted in three seasons: spring, summer, and autumn. The obtained results showed that the lawn appearance ratings varied throughout the research, both in terms of the season, the species of grass, and soil conditioners. This proves that the soil conditioner effects depend on the temperature and moisture conditions, and that there is an interaction between soil conditioners and the weather conditions affecting the grass appearance. The lawn grass species responded strongly to different weather conditions by changing their appearance in different seasons and years.
\end{abstract}

Keywords: biopreparations, grasses, lawn appearance, lawn, substral

\section{INTRODUCTION}

One of the ways to fill in the non-built-up areas in the places inhabited by people is by creating lawns; as a contrast to the monotony of inherent attributes of progress: asphalt streets, concrete blocks, and steel construction. Green spaces make human settlements liveable (Rutkowska and Dębska-Kalinowska, 2000). On the one hand, the traditional grass lawn contributes substantially to urban green space, a feature increasingly seen as valuable to human wellbeing (Tzoulas et al., 2007), and in the socioeconomics of the city, lawns are 'consumed' indirectly through their aesthetic appeal and their influence on personal viewpoints and property values (Robbins et al., 2001; Smith and Fellowes, 2014). On the other hand, the grass lawn can be viewed as a biodiversity poor monoculture that displaces indigenous landscape biota and requires large subsidies of chemicals and energy to maintain (Borman et al., 2001; Robbins and
Sharp, 2003b; Robbins, 2007), with a deleterious influence in terms of runoff and emissions that may extend considerably beyond its immediate physical location (Schueler, 2000; Robbins and Sharp, 2003a). They can be found in private gardens and public parks, cemeteries, golf courses and along roads (Ignatieva et al., 2015). Most people of the Western world view lawns as a 'natural' and even as compulsory element of the urban landscape, without questioning their social, ecological or aesthetic values (Stewart et al., 2009).

In recent years, the presence of lawns in the vicinity of residential houses and in the areas adjacent to various companies and institutions has been seen as some kind of indication of a high standard of living of their owners and as a means to improve the public image of such places (Pokorski and Siwiec, 1998; Wolski, 2003). The use of lawns in our modern society is seen as a product of our life style (Cameron et al., 2012; Czeluściński et al., 2017). 
Regardless of their kind, lawns are usually planted with grass characterised by a large variety of species, great ability to adapt to changing climatic conditions, and different ways of use (Wolski, 2003; Jankowski et al., 2012a; Jankowski et al., 2012b; Smith and Fellowes, 2014). A lawn should consist of several species of grasses, complementing each other in terms of their properties (Jankowski et al., 2012a). Selection of grass species for a lawn should depend on the habitat conditions and how much maintenance they need. Each species of grass play a unique role in the environment, human life, and economic activity (Rutkowska and Dębska-Kalinowska, 2000). Most grasses used for lawns are the varieties originating from the same few nurseries or seed mixtures, creating habitats that have no equivalent within the native environment (Ignatieva et al., 2015).

While caring for the environment in the cultivation of plants, one is looking for new, alternative solutions, not only for plant protection but also to improve soil properties. Stepień and Adamiak, (2009), Klama et al., (2010) as well as Kołodziejczyk et al., (2012) stated that one of the newly discovered in the organic system solutions, but also increasingly common in conventional systems, is based on the use of preparations of microorganisms.

Inoculation of soil microorganisms raises its biological activity, accelerating the decomposition and mineralization of organic matter (manure and other natural fertilizers, debris, post-harvest and catch crops).

In the processes of microbial transformation of organic matter, humus soil is created, the contents of which in the soil is one of the factors determining the ability of the soil to store water and nutrients (Zydlik and Zydlik, 2008). According to Shah, Saleem and Shahid (2001), Van Vliet, Bloem and De Goede (2006) and Stepień and Adamiak (2009), the introduction of microorganisms in the soil from fertilizing preparations, eliminates the sources of serious diseases that reside in the soil and crop remnants, which often contribute to the decline in the quality and lower the yields of agricultural crops. The observed positive effect of microbiological preparations (Zydlik and Zydlik, 2008; Sulewska et al., 2009; Zarzecka et al., 2011; Kołodziejczyk et al., 2012) on the increase of the yield and physiological condition of the plants, according to Klama et al., (2010) can be explained by the microbial cell secretions.
However, there are few studies on the use of this preparation in single-species cultivation of forage grasses, and thus on its impact on the chemical composition and nutritional value of these plants. Therefore, the presented issues have inspired conducting experiments in the context of the response of grasses most commonly used to sow lawns on microbiological preparations fattening soil.

The aim of this study was to determine the suitability of lawn grasses cultivated in monoculture and fertilizated by soil conditioners to establish lawn grasses used extensively in terms of their impact on the overall aspect.

\section{MATERIAL AND METHODS}

\section{Site description}

The field experiment was set up in 2012 and conducted in the experimental facility of the University of Natural Sciences and Humanities in Siedlce $\left(52^{\circ} 12^{\prime} \mathrm{N}, 22^{\circ} 28^{\prime}\right.$ E) between 2013 and 2015. The experiment was set up on the soil developed from loamy sand, belonging to anthropogenic soils, according to the Polish classification system (Technosols according to the FAO). A chemical analysis showed that the soil was alkaline, with high content of magnesium and phosphorus, and low potassium content.

\section{Experimental design}

The research was carried out as a mini-plot experiment, in the split plot design with three replications and the plot area of $1 \mathrm{~m}^{2}$. The following grass species were used in the experiment (factor B): Lolium perenne - variety Info, Festuca rubra - variety Nil, and Poa pratensis - variety Alicja. They were sown on their own, each of them at the rate of $28 \mathrm{~g} \cdot \mathrm{m}^{-2}$. Another experimental factor tested in the research was soil conditioners (factor A).

Soil conditioners used in the experiment improve the soil properties, according to the Institute of Soil Science and Plant Cultivation (IUNG) in Puławy. The composition of the soil conditioners used in the research is presented in Table 1. The soil conditioners were described in another manuscript (Jankowski et al., 2018).

The soil conditioners were applied annually in spring (mid May) in the following doses: 
UGmax $-25 \mathrm{~mL} \mathrm{~m}^{-2}(0.6 \mathrm{~L}$ in $250 \mathrm{~L}$ of water), Eko-Użyźniacz - $100 \mathrm{~mL} \mathrm{~m}^{-2}(10 \mathrm{~L}$ in $100 \mathrm{~L}$ of water), and Humus Active Papka $-250 \mathrm{~mL} \mathrm{~m}^{-2}$ (0.2 L for $10 \mathrm{~L}$ of water). In turn, Substral, a slow release fertilizer used on lawns, was used in the quantity of $20 \mathrm{~g} \mathrm{~m}^{-2}$.

\section{Data analysis}

At the end of each growing season between 2013 and 2015 an assessment of grass based on the methods described by Domański (1998) was carried out. Among other things, its general appearance was assessed in accordance with the methodology by Prończuk and Żurek (2008), using a 9-point rating scale in which 1 stands for no aesthetic value; 3 for unattractive appearance; 5 for average; 7 for attractive; 9 for very attractive. This assessment was conducted in three seasons: spring, summer, and autumn. In each year of the research, the spring assessment was made around May 20, the summer assessment around $20 \mathrm{Au}$ gust, and the autumn assessment around October
10. The meteorological data between 2013 and 2015 were obtained from the Hydrological and Meteorological Station in Siedlce.

\section{Statistical analysis}

The test results were evaluated statistically with the analysis of variance. Tukey's test $(\mathrm{P} \leq$ 0.5 ) was used to find significantly different means of the effects of experimental factors and their interaction. On the basis of the lawn appearance ratings, standard deviation and coefficient of variation were calculated for separate seasons, years, and soil conditioners.

\section{RESULTS AND DISCUSSION}

\section{Weather conditions}

The weather conditions were presented in another manuscript (Jankowski et al., 2017). The values of Sielianinov's hydrothermal coefficient

Table 1. Composition of soil conditioners applied in the experiment

\begin{tabular}{|c|c|c|c|c|c|c|c|c|c|c|c|c|}
\hline \multirow{2}{*}{$\begin{array}{c}\text { Soil } \\
\text { conditioner }\end{array}$} & \multicolumn{5}{|c|}{ Macronutrients $\left(\mathrm{g} \mathrm{kg}^{-1}\right)$} & \multicolumn{3}{c|}{ Micronutrients $\left(\mathrm{mg} \mathrm{kg}^{-1}\right)$} & \multicolumn{1}{c|}{ Microorganism and others } \\
\cline { 2 - 13 } & $\mathrm{N}$ & $\mathrm{P}$ & $\mathrm{K}$ & $\mathrm{Ca}$ & $\mathrm{Mg}$ & $\mathrm{Na}$ & $\mathrm{Mn}$ & $\mathrm{Fe}$ & $\mathrm{Zn}$ & $\mathrm{Cu}$ & $\mathrm{Mo}$ & \\
\hline $\begin{array}{c}\text { Substral } \\
\text { (S) }\end{array}$ & 220 & 21.8 & 83 & - & 12.06 & - & 12 & 50 & 12.5 & 12.5 & 1 & - \\
\hline $\begin{array}{c}\text { Humus } \\
\begin{array}{c}\text { Astive Papka } \\
\text { (HAP) }\end{array}\end{array}$ & 0.2 & 1.3 & 4.6 & 3.0 & 0.5 & - & 15 & 500 & 3 & 1 & - & $\begin{array}{l}\text { Active humus with useful } \\
\text { microorganisms }\end{array}$ \\
\hline $\begin{array}{c}\text { Eko- } \\
\text { Użyźniacz } \\
\text { (EU) }\end{array}$ & 0.6 & 0.3 & 0.7 & - & - & - & - & - & - & - & - & $\begin{array}{l}\text { Endo micorhizza, fungi, } \\
\text { bacteria, enzymes of } \\
\text { earthworms }\end{array}$ \\
\hline $\begin{array}{c}\text { UGmax } \\
\text { (UG) }\end{array}$ & 1.2 & 0.2 & 2.9 & - & 0.1 & 0.2 & 0.3 & - & - & - & $\begin{array}{l}\text { Lactic acid bacteria, } \\
\text { photosynthetic bacteria, } \\
\text { Azotobacter, Pseudomonas, } \\
\text { yeast, Actinomycetes }\end{array}$ \\
\hline
\end{tabular}

Table 2. Average air temperature $\left({ }^{\circ} \mathrm{C}\right)$ and precipitation $(\mathrm{mm})$ in individual months of the growing seasons

\begin{tabular}{|c|c|c|c|c|c|c|c|c|}
\hline \multirow{2}{*}{ Year } & \multicolumn{8}{|c|}{ Month } \\
\hline & April & May & June & July & August & September & October & Means \\
\hline \multicolumn{9}{|c|}{ Temperature $\left({ }^{\circ} \mathrm{C}\right)$} \\
\hline 2013 & 7.5 & 15.3 & 17.7 & 18.8 & 18.3 & 11.4 & 9.6 & 14.1 \\
\hline 2014 & 9.7 & 13.7 & 15.1 & 20.5 & 17.8 & 13.7 & 8.4 & 14.1 \\
\hline 2015 & 8.2 & 12.3 & 16.5 & 18.7 & 21.0 & 14.5 & 6.5 & 14.0 \\
\hline Means & 8.5 & 13.8 & 16.4 & 19.3 & 19.0 & 13.2 & 8.2 & 14.1 \\
\hline Long-term means & 8.5 & 14.0 & 17.4 & 19.8 & 18.9 & 13.2 & 7.9 & 14.2 \\
\hline \multicolumn{9}{|c|}{ Rainfall (mm) } \\
\hline 2013 & 57.6 & 145.8 & 111.9 & 49.1 & 44.1 & 86.6 & 18.0 & 73.3 \\
\hline 2014 & 39.5 & 79.5 & 74.2 & 37.5 & 105.7 & 26.3 & 3.0 & 52.2 \\
\hline 2015 & 30.0 & 100.2 & 43.3 & 62.6 & 11.9 & 77.1 & 39.0 & 52.0 \\
\hline Means & 42.4 & 108.5 & 76.5 & 49.7 & 53.9 & 63.3 & 20.0 & 59.2 \\
\hline Long-term means & 33.0 & 52.0 & 52.0 & 65.0 & 56.0 & 48.0 & 28.0 & 47.7 \\
\hline
\end{tabular}


(Skowera and Puła, 2004) for individual months of the experiment are shown in Table 3. The hydrothermal coefficients for this experiment were described in another manuscript (Jankowski et al., 2018).

\section{Lawn appearance in spring}

The lawn appearance, according to many authors (Domański, 1998; Prończuk et al., 2003; Jankowski et al., 2010; Jankowski et al., 2011) is a result of an interaction between the grass genotype and environmental conditions. The appearance ratings of the lawns (Table 4 and 7) varied throughout the experiment, both in terms of the applied soil conditioner, grass species, and weather conditions during each season. Taking into account the time of observations (spring, summer, or autumn) it turned out that weather conditions and, in particular, the distribution of rainfall had a large impact on the overall appearance of lawns.

While comparing the spring seasons, the most favourable meteorological conditions (Tables 2-3) occurred in 2013, when rainfall from April to June was twice as much as the long-term average. During that time, the temperature and moisture conditions (Table 3) were the most favourable for lawn grass. In consequence, those conditions affected the appearance of the turf. Therefore, in 2013 the ratings of lawns compared with other years were the highest. During that year, appearance rating of all grass species (Table 4) was, on average, 8.25, while in 2014 it was only $6.63^{\circ}$. The difference in the appearance assessment between experimental years was statistically significant.

According to some authors (Harkot et al., 2006; Jankowski et al., 2018; Jankowski et al., 2010) lawn appearance depends largely on the weather, which affects the growth and development of grass. The aesthetic rating of grass depends especially on the amount of precipitation in individual months of the growing season. While comparing the species of lawn grass, the highest rating of general appearance $\left(9^{\circ}\right)$ was assigned to Poa pratensis and Lolium perenne on the plots where Humus Activ Papka (HAP) was applied.

Table 3. Sielianinov's hydrothermal coefficient $(\mathrm{K})$ during the growing season

\begin{tabular}{|c|c|c|c|c|c|c|c|}
\hline \multirow{2}{*}{ Years } & \multicolumn{7}{|c|}{ Month } \\
\cline { 2 - 8 } & Apr. & May & June & July & Aug. & Sept. & Oct. \\
\hline 2013 & $2.56(\mathrm{vw})$ & $3.07(\mathrm{ew})$ & $2.11(\mathrm{w})$ & $0.84(\mathrm{~d})$ & $0.78(\mathrm{~d})$ & $2.53(\mathrm{vw})$ & $0.60(\mathrm{vd})$ \\
\hline 2014 & $1.36(\mathrm{o})$ & $1.87(\mathrm{qw})$ & $1.64(\mathrm{qw})$ & $0.59(\mathrm{vd})$ & $1.92(\mathrm{qw})$ & $0.64(\mathrm{vd})$ & $0.12(\mathrm{ed})$ \\
\hline 2015 & $1.22(\mathrm{qd})$ & $2.63(\mathrm{vw})$ & $0.87(\mathrm{~d})$ & $1.08(\mathrm{qd})$ & $0.18(\mathrm{ed})$ & $1.46(\mathrm{o})$ & $1.94(\mathrm{qw})$ \\
\hline
\end{tabular}

Table 4. Grass appearance rating (9 point scale) in spring seasons of 2013-2015.

\begin{tabular}{|c|c|c|c|c|c|c|}
\hline \multirow{2}{*}{$\begin{array}{l}\text { Year } \\
\text { (C) }\end{array}$} & \multirow{2}{*}{$\begin{array}{l}\text { Species } \\
\text { (B) }\end{array}$} & \multicolumn{4}{|c|}{ Soil conditioner $(\mathrm{A})$} & \multirow{2}{*}{$\bar{x}$} \\
\hline & & $(\mathrm{S})$ & $(E U)$ & (HAP) & (UG) & \\
\hline \multirow{3}{*}{2013} & Poa pratensis & 8.9 & 8.4 & 9.0 & 8.4 & 8.68 \\
\hline & Lolium perenne & 8.2 & 7.3 & 9.0 & 7.4 & 7.98 \\
\hline & Festuca rubra & 8.4 & 7.3 & 8.4 & 8.3 & 8.10 \\
\hline \multirow{3}{*}{2014} & Poa pratensis & 8.6 & 4.4 & 3.2 & 7.7 & 5.98 \\
\hline & Lolium perenne & 8.7 & 5.1 & 4.9 & 8.9 & 6.90 \\
\hline & Festuca rubra & 7.6 & 6.4 & 6.2 & 7.8 & 7.00 \\
\hline \multirow{3}{*}{2015} & Poa pratensis & 6.7 & 7.9 & 6.8 & 8.2 & 7.40 \\
\hline & Lolium perenne & 9.0 & 8.0 & 8.1 & 7.1 & 8.05 \\
\hline & Festuca rubra & 9.0 & 9.0 & 8.9 & 8.8 & 8.93 \\
\hline \multicolumn{7}{|c|}{ Average species effect } \\
\hline & Poa pratensis & 8.07 & 6.90 & 6.33 & 8.10 & 7.35 \\
\hline & Lolium perenne & 8.63 & 6.80 & 7.33 & 7.80 & 7.64 \\
\hline & Festuca rubra & 8.33 & 7.57 & 7.83 & 8.30 & 8.01 \\
\hline \multicolumn{7}{|c|}{ Average soil conditioner effect } \\
\hline & Soil conditioners & 8.34 & 7.09 & 7.16 & 8.07 & 7.67 \\
\hline \multicolumn{7}{|c|}{ Average ratings in individual years } \\
\hline & 2013 & 8.50 & 7.67 & 8.80 & 8.03 & 8.25 \\
\hline & 2014 & 8.30 & 5.30 & 4.77 & 8.13 & 6.63 \\
\hline & 2015 & 8.23 & 8.30 & 7.93 & 8.03 & 8.12 \\
\hline
\end{tabular}


A high rating of lawn appearance in the spring of 2015 indicates a positive response of the grasses to weather conditions, although in April they were specified as quite dry and in June as dry (Table 3). During this period, despite relatively unfavourable weather in those months, the general appearance ratings were fairly high (from $6.7^{\circ}$ to $9^{\circ}$ ) because this result was affected by high precipitation in May, which was twice higher than the long-term average (Table 4). During the growing season of 2015, while comparing grass from all plots, it turned out that lower ratings of general appearance were assigned to the lawns of $\mathrm{Poa}$ pratensis $\left(7.4^{\circ}\right)$ and Lolium perenne $\left(8.05^{\circ}\right)$. In turn, Festuca rubra looked the best (on average $8.93^{\circ}$ ), which confirms the fact that this grass species grows well even under unfavourable moisture conditions. The rating of the appearance of this grass ranged from $8.8^{\circ}$ to $9^{\circ}$, classified as very attractive. Out of all soil conditioners applied in the experiment, Eko-Użyźniacz (EU) and Substral (S) were the most effective. Similarly, Truba et al. (2017) found that Lolium perenne had the highest biomass when Eko-Użyźniacz was applied together with NPK fertilisers.

The results of the assessment of grass general appearance (Table 4) indicate that in the spring seasons Festuca rubra was assigned, on average, the highest rating $\left(8.01^{\circ}\right.$ ) and Poa pratensis the lowest $\left(7.35^{\circ}\right)$. Prończuk et al., (2003) obtained slightly different results, i.e. the lawn varieties of Festuca rubra had lower ratings of general appearance in spring than in summer or autumn. While comparing grass species and a type of fertilization it was noted that in spring (Table 4) the highest rating of the general appearance $\left(8.63^{\circ}\right)$ was assigned to Lolium perenne with Substral applied, and the lowest to Poa pratensis with $\mathrm{Hu}-$ mus Active Papka $\left(3.33^{\circ}\right)$. While assessing the impact of soil conditioners on general appearance ratings in spring seasons, it turned out that regardless of the species, Substral was the most effective, with the score of $8.34^{\circ}$, and Eko-Użyźniacz the least $\left(7.09^{\circ}\right)$.

\section{Lawn appearance in summer}

While comparing all the summer seasons (Table 5) the most adverse weather conditions were in 2015 (Table 3), when July was quite dry and August extremely dry, and in 2013, when drought occurred in July and August. Those meteorological conditions affected the general appearance of grasses, with the lowest rating values of $6.25^{\circ}$ in 2015 and $6.67^{\circ}$ in 2013. However, in 2014, when August was quite wet, the appearance rating value was, on average, $8.84^{\circ}$. During that year all the grasses on the plots with Eko-Użyźniacz applied received the highest rating $\left(9^{\circ}\right)$. Similarly, in the studies of Sąkol et al., (2012) the application of Eko-Użyźniacz on Heuchera micrantha growing on its own increased participation of leaves and florescence in the yield, compared to the control object. While analysing the species of lawn grass in the present experiment it was observed that during summer months (regardless of fertilization) Lolium perenne had the highest appearance rating (on average $8.13^{\circ}$ ), and Festuca rubra the lowest $\left(6.37^{\circ}\right)$.

While comparing interaction between grass species and soil conditioners in summer seasons it was found that Lolium perenne with UGmax had the highest overall appearance rating $\left(8.8^{\circ}\right)$ and Poa pratensis on the plots with Humus applied had the lowest rating $\left(5.87^{\circ}\right)$. Sosnowski (2012), applying both UGmax and mineral fertilizer, observed that Lolium perenne responded with a significant increase in the number of shoots, leaf lamina length, leaf base width, and leaf greenness index. Additionally, Truba et al., (2017), also in an experiment with Lolium perenne, found the lowest biomass increase when Humus Active Papka was applied on its own. In the present experiment, comparing the effects of the soil conditioners on all grass species, UG-max and Substral had the highest impact on lawn appearance $\left(7.9^{\circ}\right)$ and $\mathrm{Hu}-$ mus the lowest $\left(6.4^{\circ}\right)$. In the studies of Truba et al., (2017) mentioned above, comparing all fertilizer combinations they noted the lowest biomass increase in both Dactylis glomerata and Lolium perenne when Humus Active was used.

\section{Lawn appearance in autumn}

Throughout the experiment, a large variability of meteorological conditions was also observed in the autumn seasons (Tables 2-3). In the autumn of 2014 (Table 3), the temperature and moisture conditions for the growth and development of the grass were the worst. In September it was very dry, and in October, the conditions worsened even more, to extremely dry. In the same month of 2014, the amount of rainfall (Table 2) was the lowest not only that year but when all the months of three years of research are compared. These conditions were reflected in the 
grass appearance rating (Table 6). In the autumn of 2014 grass had the lowest appearance rating (an average of $4.58^{\circ}$ ), while in 2013 it was $8.83^{\circ}$. The difference between grass appearance ratings in all the years was statistically significant.

The general appearance in autumn 2013 was positively affected by very favourable temperature and moisture conditions, especially in September (Tables 2-3), with plenty of rainfall, nearly twice as much as the long-term average. The fact that in the autumn of 2013, comparing the effects of both grass species and soil conditioners, only minimal differences in lawn appearance ratings were observed, is noteworthy. However, in the autumn of 2014 , with a continuing permanent drought, Lolium perenne looked the best of all grasses (on average $5.75^{\circ}$ ). What is more, throughout the experiment in the autumn seasons, Lolium perenne

Table 5. Grass appearance rating (9 point scale) in summer seasons of 2013-2015

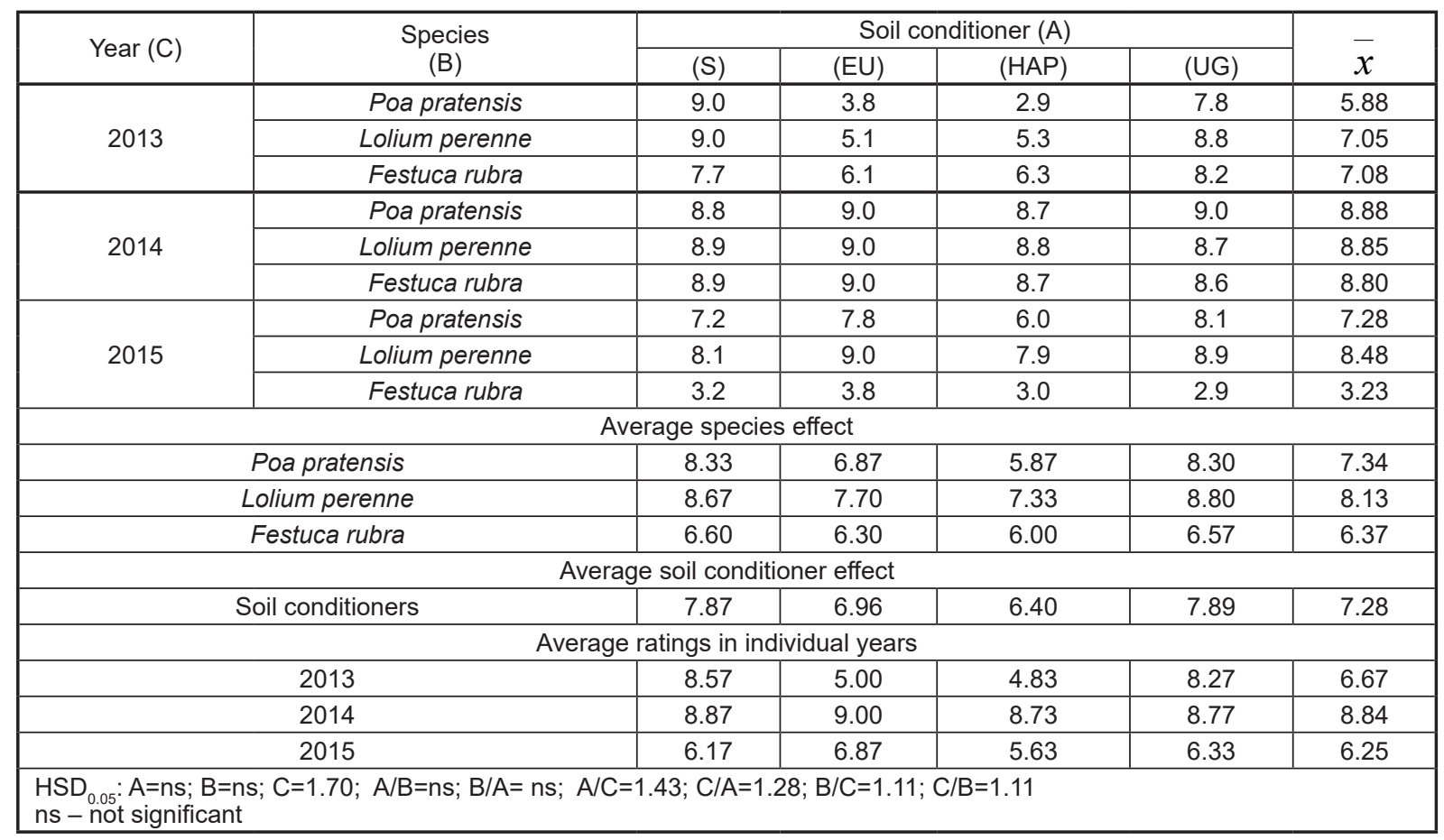

Table 6. Grass appearance rating (9 point scale) in autumn seasons of 2013-2015

\begin{tabular}{|c|c|c|c|c|c|c|}
\hline \multirow{2}{*}{$\begin{array}{l}\text { Year } \\
\text { (C) }\end{array}$} & \multirow{2}{*}{$\begin{array}{l}\text { Species } \\
\text { (B) }\end{array}$} & \multicolumn{4}{|c|}{ Soil conditioner $(\mathrm{A})$} & \multirow{2}{*}{$\bar{x}$} \\
\hline & & (S) & $(E U)$ & (HAP) & (UG) & \\
\hline \multirow{3}{*}{2013} & Poa pratensis & 8.9 & 9.0 & 9.0 & 8.6 & 8.88 \\
\hline & Lolium perenne & 9.0 & 8.9 & 8.5 & 8.9 & 8.83 \\
\hline & Festuca rubra & 8.8 & 9.0 & 8.6 & 8.7 & 8.78 \\
\hline \multirow{3}{*}{2014} & Poa pratensis & 3.8 & 3.2 & 3.1 & 3.3 & 3.35 \\
\hline & Lolium perenne & 4.9 & 6.0 & 6.2 & 5.9 & 5.75 \\
\hline & Festuca rubra & 5.4 & 4.1 & 5.2 & 3.9 & 4.65 \\
\hline \multirow{3}{*}{2015} & Poa pratensis & 7.3 & 6.9 & 5.8 & 6.1 & 6.53 \\
\hline & Lolium perenne & 7.9 & 6.7 & 7.8 & 6.9 & 7.33 \\
\hline & Festuca rubra & 3.9 & 3.8 & 4.0 & 4.2 & 3.98 \\
\hline & \multicolumn{6}{|c|}{ Average species effect } \\
\hline & Poa pratensis & 6.67 & 6.37 & 5.97 & 6.00 & 6.25 \\
\hline & Lolium perenne & 7.27 & 7.20 & 7.50 & 7.23 & 7.30 \\
\hline & Festuca rubra & 6.03 & 5.63 & 5.93 & 5.60 & 5.80 \\
\hline \multicolumn{7}{|c|}{ Average soil conditioner effect } \\
\hline & Soil conditioners & 6.66 & 6.40 & 6.47 & 6.28 & 6.45 \\
\hline \multicolumn{7}{|c|}{ Average ratings in individual years } \\
\hline & 2013 & 8.90 & 8.97 & 8.70 & 8.73 & 8.83 \\
\hline & 2014 & 4.70 & 4.43 & 4.83 & 4.37 & 4.58 \\
\hline & 2015 & 6.37 & 5.80 & 5.87 & 5.73 & 5.94 \\
\hline
\end{tabular}


Table 7. Grass appearance rating in relation to grass species and soil conditioners (the average of 2013-2015)

\begin{tabular}{|c|c|c|c|c|c|}
\hline \multirow{2}{*}{$\begin{array}{l}\text { Species } \\
\text { (B) }\end{array}$} & \multicolumn{4}{|c|}{ Soil conditioner $(\mathrm{A})$} & \multirow{2}{*}{$\bar{x}$} \\
\hline & $(\mathrm{S})$ & $(E U)$ & (HAP) & $(\mathrm{UG})$ & \\
\hline Poa pratensis & 7.69 & 6.71 & 6.05 & 7.47 & 6.98 \\
\hline Lolium perenne & 8.19 & 7.23 & 7.39 & 8.06 & 7.72 \\
\hline Festuca rubra & 6.99 & 6.50 & 6.59 & 6.82 & 6.73 \\
\hline \multicolumn{6}{|c|}{ Average soil conditioner effect } \\
\hline & 7.62 & 6.81 & 6.68 & 7.45 & 7.14 \\
\hline \multicolumn{6}{|c|}{ Average ratings in individual years } \\
\hline 2013 & 8.66 & 7.21 & 7.44 & 8.34 & 7.92 \\
\hline 2014 & 7.29 & 6.24 & 6.11 & 7.09 & 6.68 \\
\hline 2015 & 6.92 & 6.99 & 6.48 & 6.69 & 6.77 \\
\hline
\end{tabular}

Table 8. Standard deviation and coefficient of variation of lawn appearance rating

\begin{tabular}{|c|c|c|c|c|c|}
\hline Species & Min. rating & Max. rating & Mean values & Standard deviation & Coefficient of variation \\
\hline Poa pratensis & 2.9 & 9 & 6.98 & 2.12 & 30.37 \\
\hline Lolium perenne & 4.8 & 9 & 7.69 & 1.40 & 18.21 \\
\hline Festuca rubra & 2.9 & 9 & 6.73 & 2.18 & 32.39 \\
\hline
\end{tabular}

Coefficient of variation: $0-20 \%$ small variability, $20-40 \%$ medium variability, $40-60 \%$ large variability, > $60 \%$ very large variability.

had the highest average appearance rating $\left(7.30^{\circ}\right)$ and Festuca rubra the lowest $\left(5.80^{\circ}\right)$. While comparing the effects of soil conditioners on all grass species throughout the experiment it was noted that they did not differentiate lawn appearance rating significantly, with $6.28^{\circ}$ for UGmax and 6 . $66^{\circ}$ for Substral.

\section{Durability of appearance}

The experiment showed that for all observations (spring, summer, or autumn), the appearance ratings (Table 7) varied significantly throughout the research both in terms of grass species and soil conditioners. Additionally, Jankowski et al., (2012a) while assessing lawns with different species of grass grown on their own, found that the appearance ratings varied considerably throughout the experiment in terms of particular grass species and the time of observation.

Throughout all growing seasons, out of all grass species Lolium perenne had the highest rating (an average of $7.72^{\circ}$ ) and Festuca rubra the lowest $\left(6.73^{\circ}\right)$. Grass treated with Substral looked the best (on average $7.62^{\circ}$ ), and this conditioner was the most effective for all grass species tested in the experiment. While comparing all growing seasons, the lawns looked the best in 2013 (an average rating of $7.92^{\circ}$ ), while with regard to soil conditioners grass was at its best as a result of Substral application also in 2013 (on average $8.66^{\circ}$ ).
By analysing the durability of appearance ratings in relation to particular grass species (Table 8 ) it turned out that coefficient of variation for Lolium perenne was the most favourable, indicating moderate variability. For Poa pratensis and Festuca rubra the coefficient of variation of appearance rating was above $30 \%$, indicating large variability. Therefore, to create a lawn, Lolium perenne, both on its own and in mixtures, should be recommended first of all.

\section{CONCLUSIONS}

The lawn appearance ratings varied throughout the research, both in terms of the season (spring, summer, and autumn), the species of grass (Poa pratensis, Lolium perenne, and Fesctuca rubra), and soil conditioners. The weather conditions in different growing seasons, and, in particular, the amount of precipitation largely affected the lawn appearance. Out of the soil conditioners, Substral applied in spring and autumn and UGmax used in summer had the most positive effect on the grass. This proves that the soil conditioner effects depend on the temperature and moisture conditions, and that there is an interaction between soil conditioners and the weather conditions affecting the grass appearance. The lawn grass species responded strongly to different weather conditions by changing their appearance in different seasons and years. From a practical 
point of view, out of the grass species tested in the experiment, Lolium perenne treated with Substral responded the most favourably.

\section{Acknowledgements}

The research carried out under the theme No 213/04/S was financed by the science grant of the Ministry of Science and Higher Education - Poland.

\section{REFERENCES}

1. Bac S., Koźmiński C., Rojek M. 1993. Agrometeorology. PWN, Warsaw (Poland), 32-33.

2. Borman F.H., Balmori D., Geballe T.G. 2001. Redesigning the American Lawn. A Search for 443 Environmental Harmony. Yale University Press, New Haven/London.

3. Cameron R.W.F., Blanusa T., Taylor J.E., Salisbury A., Halstead A.J., Henricot B., Thompson K. 2012. The domestic garden - its contribution to urban green infrastructure. Urban Forestry \& Urban Greening, 11, 129-137. Doi:10.1016/j. ufug.2012.01.002

4. Czeluściński W., Jankowski K., Sosnowski J., Malinowska E., Wiśniewska-Kadżajan B. 2017. Effects of trinexapac-ethyl on turfgrass growth and frequency of mowing. Applied Ecology and Environmental Research, 15(3), 739-746.

5. Domański P. 1998. Methodology of study of economic value of cultivars (WGO) of cultivated crops. Turf grass. COBORU, Słupia Wielka (Poland), $1-35$.

6. Harkot W., Czarnecki Z., Powroźnik M., Rosołowski G. 2006. Influence of mowing frequency on general aspect of turf of selected Festuca ssp. cultivars during seven-years performance. Grassland Science in Poland, 9, 59-65.

7. Ignatieva M., Ahrné K., Wissman J., Eriksson T., Tidåker P., Hedblom M. 2015. Lawn as a cultural and ecological phenomenon: A conceptual framework for transdisciplinary research. Urban Forestry \& Urban Greening, 14, 383-387. Doi:10.1016/j. ufug.2015.04.003

8. Jankowski K., Czeluściński W., Jankowska J., Ciepiela G.A. 2010. Effect of aquagel on the initial development of turfgrasses and their aesthetical value. Journal of Research and Applications in Agricultural Engineering, 55(2), 36-41.

9. Jankowski K., Czeluściński W., Jankowska J. 2011. Effect of hydrogel and type of fertilizer on the turf compactness with varying participation of perennial ryegrass in mixture. Folia Pomeranae Univer- sitatis Technologiae Stetinensis, 286(18), 13-22.

10. Jankowski K., Sosnowski J., Jankowska J. 2012a. General aspect of turf lawns established on the base of tufted hair grass. Fragmenta Agronomica, 29(1), 25-33.

11. Jankowski K., Czeluściński W., Jankowska J., Kolczarek R., Sosnowski J. 2012b. The influence of the growth regulator trinexsapac ethyl on the regrowth rate of lawns grasses. Acta Scientarium Polonorum Hortorum Cultus, 11(4), 67-76.

12. Jankowski K., Sosnowski J., Truba M., Skrzyczyńska J., Malinowska E., Wiśniewska-Kadżajan B. 2017. Impact of soil conditioners and weather on lawn compactness. Applied Ecology and Environmental Research 15(4), 1917-1928.

13. Jankowski K., Malinowska E., Wiśniewska-Kadżajan B., Jankowska J., Truba M., Czeluściński W., Koper O., Góral P., Kania P., Matsyura A. 2018. The effects of soil conditioners on grass colour throughout the growing season. Applied Ecology and Environmental Research 16(4): 3981-3992.

14. Klama J., Jędryczka M., Wiśniewska H., Gajewski P. 2010. Evaluation of development and physiological stage of winter wheat and winter oilseed rape plants grown with the application of effective microorganisms. Science Nature Technology, 4(6), \#81.

15. Kołodziejczyk M., Szmigiel A., Kulig B. 2012. Yielding of spring wheat under conditions of differentiated nitrogen fertilization and application of microbiological preparations to improve soil properties. Fragmenta Agronomica, 29(1), 60-69.

16. Pokorski J., Siwiec A. 1998. Shaping of green areas. WSiP Warsaw (Poland), 232-233.

17. Prończuk S., Żurek D. 2008. The relationship between sod strength and turf quality of common grass cultivars. Bulletin of Plant Breeding and Seed Science, 57, 25-34.

18. Prończuk M., Prończuk M., Laudański Z., Prończuk S. 2003. Comparison of species and cultivars of Festuca spp: in many-years of turf maintenance. Bulletin of Plant Breeding and Seed Science, 225, 239-257.

19. Robbins P. 2007. Lawn People. How Grasses, Weeds and Chemicals Make Us Who We Are. Temple University Press, Philadelphia.

20. Robbins P., Polderman A., Birkenholtz T. 2001. Lawns and toxins: an ecology of the city. Cities, 18 , 369-380. Doi:10.1016/S0264-2751(01)00029-4

21. Robbins P., Sharp J. 2003a. The lawn-chemical economy and its discontents. Antipode, 35, 955979. Doi:10.1111/j.1467-8330.2003.00366.x

22. Robbins P., Sharp J. 2003b. Producing and consuming chemicals: the moral economy of the American lawn. Economic Geography, 79, 425-451. 
23. Rutkowska B., Dębska-Kalinowska Z. 2000. Usefulness of species and varieties of grasses on lawns. Wieś Jutra 4(21), 19-22.

24. Sąkol G., Niesler A., Pawełko K., Trelka T. 2012. Evaluation of development of three cultivars of coral bells (heuchera) after application of organic means of improving soil properties and mineral fertilizers on post-mining area of the Dąbrowskie Coal Basin. Science Nature Technology, 6(4), 70.

25. Schueler T. 2000. Urban pesticides: from the lawn to the stream. Watershed Protection Techniques, 2, 247-253.

26. Shah H.S., Saleem M.F., Shahid M. 2001. Effect of different fertilizers and effective microorganisms on growth, yield and quality of maize. International Journal of Agriculture \& Biology, 3, 378-379.

27. Skowera B., Puła J. 2004. Pluviometric extreme conditions in spring season in Poland in the years 1971-2000. Acta Agrophysica, 3(1), 171-177.

28. Smith L.S. Fellowes M.D.E. 2014. The grass-free lawn: Management and species choice for optimum ground cover and plant diversity. Urban Forestry \& Urban Greening,13, 433-442. Doi:10.1016/j. ufug.2014.04.008

29. Sosnowski J. 2012. Reaction of Dactylis glomerata L., Festuca pratensis Huds. and Lolium perenne L. to microbiological fertilizer and mineral fertilization. Acta Scienitarum Polonorum s. Agriculture, 11(1), 91-98.

30. Stewart G.H., Ignatieva M.E., Meurk C.D., Buckley H., Horne B., and Braddick T. 2009. Urban biotopes of Aotearoa New Zealand (URBANZ) (I): composition and diversity of temperate urban lawns in Christchurch. Urban Ecosystems, 12, 233-248. Doi:10.1007/s11252-009-0098-7

31. Stępień A., Adamiak E. 2009. Effective microorganisms (Em-1) and their influence on occurrence of cereal diseases. Progress in Plant Protection, 49(4), 2028-2030.

32. Sulewska H., Szymańska G., Pecio A. 2009. Evaluation of UGmax soil additive applied in maize grown for grain and silage. Journal of Research and Application in Agriculture Engineering, 54(4), 120-124.

33. Truba M., Wiśniewska-Kadżajan B., Sosnowski J., Malinowska E., Jankowski K. Makarewicz A. 2017. The effect of soil conditioners on cellulose, hemicellulose and the ADL fibre fraction concentration in Dactylis glomerata and Lolium perenne. Journal of Ecological Engineering, 18(1), 107-112. Doi: $10.12911 / 22998993 / 66249$

34. Tzoulas K., Korpela K., Venn S., Yli-Pelkonen V., Kaźmierczak A., Niemela J., James P. 2007. Promoting ecosystem and human health in urban areas using Green Infrastructure: a literature review. Landscape and Urban Planning, 81, 167-179. Doi:10.1016/j.landurbplan.2007.02.001

35. Wolski K. 2003. The importance of grasses in human life and the protection of the environment. PTNA, WTN Wrocław (Poland), 1-10.

36. Van Vliet P.C.J., Bloem J., De Goede R.G.M. 2006. Microbial diversity, nitrogen loss and grass production after addition of Effective Micro-organisms ${ }^{\circledR}$ (EM) to slurry manure. Applied Soil Ecology, 32, 188-198. Doi:10.1016/j.apsoil.2005.07.001

37. Zarzecka K., Gugała M., Milewska A. 2011. Effect of soil fertilizer UGmax on potato yielding and plant health. Progress in Plant Protection., 51(1), 153-157.

38. Zydlik P., Zydlik Z. 2008. Impact of biological effective microorganisms (EM) preparations on some physico-chemical properties of soil and the vegetative growth of apple-tree rootstocks. Science Nature Technologies, 2(1), 1-8. 